\title{
Audience Reception Research in a Post-broadcasting Digital Age
}

\author{
Schrøder, Kim Christian
}

Published in:

Television \& New Media

DOI:

$10.1177 / 1527476418811114$

Publication date:

2019

Document Version

Peer reviewed version

Citation for published version (APA):

Schrøder, K. C. (2019). Audience Reception Research in a Post-broadcasting Digital Age. Television \& New Media, 20(2), 155-169. https://doi.org/10.1177/1527476418811114

\section{General rights}

Copyright and moral rights for the publications made accessible in the public portal are retained by the authors and/or other copyright owners and it is a condition of accessing publications that users recognise and abide by the legal requirements associated with these rights.

- Users may download and print one copy of any publication from the public portal for the purpose of private study or research.

- You may not further distribute the material or use it for any profit-making activity or commercial gain.

- You may freely distribute the URL identifying the publication in the public portal.

\section{Take down policy}

If you believe that this document breaches copyright please contact rucforsk@kb.dk providing details, and we will remove access to the work immediately and investigate your claim. 
Kim Christian Schrøder

Audience reception research in a post-broadcasting digital age

Professor

Department of Communication, Roskilde University

Email: kimsc@ruc.dk

Address:

Roskilde University, Building 40.3, Universitetsvej 1, DK-4000 Roskilde, Denmark,

Phone: Work: (+45) 467438 08, Mobile (+45) 40985378

Kim Christian Schroder is Professor of Communication at the Department of Communication and Arts, Roskilde University, Denmark. His books in English include Audience Transformations: Shifting Audience Positions in Late Modernity (co-edited, 2014), Museum Communication and Social Media: The Connected Museum (co-edited 2013), and Researching Audiences (co-authored, 2003). His research interests comprise the analysis of audience uses and experiences of media. His recent work explores mixed methods for mapping news consumption.

Audience reception research was a child of the broadcasting age, emerging strongly as a sub-discipline in media and communication research in the 1980s. Many saw reception research as a cross-fertilizing force theoretically and methodologically, bringing together research traditions from the humanities and the social sciences, and adding a qualitative orientation to the near-hegemonic rule of quantitative methods in audience research. This article discusses the ways in which reception research is reinventing itself in a postbroadcasting age. With sense-making processes as the continued key concern, three transformations are affecting the trajectory of reception research: an empirical shift has occurred from analyzing viewers' 'decoding' encounter with media 'texts', to mapping audience participation in the wider mediascapes of traditional, digital, and social media; a theoretical adoption of, and contributions to, theories of participation and mediatization; and a methodological shift from purely qualitative to a mixed-method research designs.

Keywords: audiences, reception, mixed-methods, sense-making, mediatization, post-broadcasting 
In the current scholarly climate of audience research, where theoretical interdisciplinarity and methodological complementarity appear to have become the new normal, it may sound strange to the ears of young generations of audience researchers that little over three decades ago, social scientific and cultural paradigms of audience analysis were generally perceived to be, in the words of two prominent representatives of the social science tradition, "altogether incompatible" (Blumler, Gurevitch and Katz 1985, 271). Conversely, within humanistic and cultural media research there was widespread reluctance, if not outright refusal, to study audiences empirically (Jensen 1986, 23). The state of the world before reception research was succinctly summarized by Elihu Katz and Tamar Liebes (two of the pioneers of then embryonic reception research): "Some of us are studying the texts of popular culture while others are studying their effects on audiences. (...) The former (...) don't know anything about the audience, and the latter (...) don't know anything about the texts" (Katz \& Liebes 1985, 4-5). From this point of departure it became the historical mission of reception research to shed empirical light on how audiences make sense of their encounters with mass media, especially television programs.

This article takes its point of departure in this heritage, and considers whether reception research still has a contribution to make in the post-broadcasting, digital age. I shall demonstrate through analytical examples that an emic everyday life perspective on people's uses of digital and social media is as indispensable as it was when our cultural universe consisted of print and broadcast media; that understanding audiences' acts of engagement is necessary to conceptualize processes of mediatization; that tracking-data about digital media use has little value if not contextualized by qualitative contextual insights; and that reception research can play an innovative methodological role by integrating qualitative and quantitative tools. 
This is not the place to recount the historical struggles through which reception research established itself as a new paradigm (see Schrøder 1987; Jensen \& Rosengren 1990), but a few words are in order to portray the main constituents of the then scholarly newcomer. On the one hand, early reception researchers did recognize that the paradigm of uses and gratifications research had transformed the previously dominant tradition of effects research, by famously asking not what the media do to people, but what people do with the media; where reception researchers found uses and gratifications research wanting was in its lack of attention to how audiences make sense of the media they use.

On the other hand, reception research also aimed its critical fire on the speculative insights about media influence offered by humanistic analysis of media texts, on the basis of the scholars' analytical introspection: "Guesswork indulged in within the walls of academia must be replaced, or supplemented, by fieldwork requiring expeditions into the real world of the audience" (Schrøder 1987, 17).

\section{The DNA of early reception research}

Poised between these two entrenched paradigms of the social sciences and the humanities and, as Klaus Bruhn Jensen polemically put it, taking its theory from the humanities and its method from the social sciences (Jensen 1991, 135), David Morley - author of early authoritative work on reception - defined reception as the semiotic process through which "audiences differentially read and make sense of messages which have been transmitted, and act on those meanings, within the context of the rest of their situation and experience" (Morley 1980, 11). 
In this brief definition we find some keywords which taken together may serve to make the theoretical DNA of early reception research explicit: the word 'read' encapsulates the insistence that mediated communication is not simply about 'transmitting' a message from senders to receivers; it is, on the contrary, a 'sense-making' process that requires natural as well as acquired literacy skills, not just for interpreting alphabetically-based 'texts' (cf. Janice Radway's 'Reading the Romance” (1984), but also for 'Reading Television', as John Fiske and John Hartley (1978) significantly titled their seminal book. As this mind-set was imported from media studies into communication research, "the sense-making approach" even became the brand name of Dervin's revolutionizing redefinition of campaign research (Dervin 1989).

The term 'read' also invokes associations with the semiotic roots of reception research, which were made explicit in Stuart Hall's canonical paper (Hall 1973; Gurevitch \& Scannell 2003) about the need to theorize and empirically explore the 'encoding' and 'decoding' of television discourses. As it turned out, the time around 1980 was ripe for the reception-analytical focusing on the meaningmaking 'decoding' practices of audiences, while it took a couple of decades until the encodings of media producers became part of the research agenda (Deacon et al. 1999).

As an antidote to potentially individualizing understandings of what reception was about, Morley's definition also specified that people's meaning-making from media discourses must be studied in their societal 'contexts' as well as their 'situational' circumstances of place and time. The social context requirement was built into the Marxist knowledge interest of early reception research, whose whole raison d'etre was to understand how class-based audience groups would perform their ideologically loaded 'dominant readings' of the (news) media's hegemonic 'preferred meaning', designed to win consent for a social order based on the class dominance of the ruling class, while not-so-compliant audiences would also have the possibility to read this ideological message in 'negotiated' or 'oppositional ways. In later times, when class-oriented Marxist analysis (Morley 
1980; Fiske 1987) was supplanted by other forms of critical knowledge interests, reception research would focus, for instance, on the ways in which heteronormative media portrayals of gender were experienced by people with variety of gender-cultural orientations (Dhoest 2009), just as relations of mediated cultural power were analyzed from an ethnic perspective (Gillespie 1995).

The 'situational' requirement typically manifested itself in analyses of how television culture played out in domestic, often gendered, patriarchal contexts, for instance David Morley's study in Family Television (1986) of struggles over television channel and program selection; Ann Gray's study of women's use of video recorders as an emancipatory technology (Gray 1992); or James Lull's semiethnographic analysis of the ways American families orchestrate domestic everyday life around television Lull 1980; see also Ang 1995).

One additional characteristic of early reception research was the concern with the possible cultural imperialism (Schiller 1971) inherent in the massive import of American popular culture products, especially tv serials, across the globe. On the whole, reception studies of how local populations made sense of soap operas like Dallas and Dynasty served to allay the fears of other cultures being culturally overrun by these American series: local viewers' interpretations turned out to be solidly anchored in indigenous cultures (Liebes \& Katz 1990), and they vastly preferred equivalent domestically produced to the US imports (Biltereyst 1991; see also Livingstone 1988). More generally this research also spoke to a research-political agenda, which was inherited from the emerging cultural studies paradigm (Hoggart 1957; Williams 1958) aiming to rehabilitate popular culture as a legitimate object of academic study and as potentially holding cultural quality for its devoted, and aesthetically sophisticated, audiences (Schrøder 1992).

Not too surprisingly in light of such knowledge interests, the founding mothers and fathers of reception research insisted that mediated sense-making could only be studied with qualitative 
methods. It was the purpose of empirical fieldwork, typically in the form of individual or focus group interviews, to elicit audiences' narratives and verbalized meanings about their media experiences, and next to apply bottom-up, grounded theory analytical methods to distil the mosaics of meaning created by audience members from the encounter with media texts.

\section{Reception research - trajectory into the digital age}

We now live in a different media systemic regime of digital, mobile and participatory media, with media use taking place not just, or even mainly, in the home, but as the saying goes 'anywhere any time'. In skeletal form, the way in which the historical journey of reception research since the 1970s has accompanied the revolutionizing technological and cultural developments over four decades has been interpreted by Schrøder (2012a) in the form of five consecutive, and to some extent overlapping, stages of reception research, focusing on reception analytical works which have explored the citizenship and the workings of mediated democracies in the areas of televised news and current affairs.

The first stage (hegemonic citizenship, app. 1973-1990) corresponds to the portrait presented above, where reception research analyzed the formation of political consciousness in a class-divided society (Hall 1973; Morley 1980). The second stage (monitorial citizenship, app. 1985 onwards) adopted a less politically radical critique of the news media. The aim was to find out how news media equipped citizens to function as political subjects in a representative democracy, by enabling them to monitor and understand what is going on and how democratic society works (Jensen 1986; Lewis 1991). 
The third stage (popular citizenship, app. 1994 onwards) saw the appearance of Livingstone \& Lunt's (1994) ground-breaking study of the reception of studio debate programs. This study was unique in adding a quantitative survey study to the primary qualitative one, in order to corroborate the qualitative findings on a representative scale (Livingstone, et al. 1994).

The fourth stage (participatory citizenship, app. 2000 onwards) reflected the reception analytical interests that arose as a response to the emerging convergence culture with its initially predominantly utopian expectations that the digital affordances would lead to higher levels of political participation and mediated activism among audiences (Carpentier 2003).

Finally, the fifth stage (ubiquitous citizenship, app. 2005 onwards) sees the emergence of citizenship-oriented reception research - citizenship being 'ubiquitous', both because smartphones enable media use spatially anywhere and temporally anytime, and because, in the words of Jeffrey Jones, the realm of the political has been extended beyond Habermas's 'public sphere: "We engage politics everywhere, all the time, and the media are central to that engagement" (Jones 2006, 9). The work of Irene Costera Meijer is emblematic of this stage, as - using a diverse range of methods: surveys, focus groups, diaries, etc. - she analyzes people's perceptions of news content accessed on different devices, as well as news consumers' navigation practices in all areas of the cross-media landscape (Costera Meijer 2007; Kormelink \& Costera Meijer 2017).

\section{Is there a role for reception research in the post-broadcasting age?}

The latest addition to the story told in the previous section has been accomplished by the participants in the CEDAR network - the Consortium on Emerging Directions in Audience 
Research, populated by early-career scholars in audience and reception research, whose impressive final report (Das \& Ytre-Arne 2018) has combined, on behalf of audience research, both hindsight and foresight endeavors, which map the past achievements as well as the desired future directions of audience and reception research. One of CEDAR's research priorities for the future, as they single out the overall need to better understand the current challenges of emerging intrusive media technologies and the internet of things, manifests itself as an explicit plea for continuing the fundamental agenda instituted by reception research in its formative years.

Noting that much digital media research today is heavily platform-focused, it is Das \& Ytre-Arne's first priority to argue for the urgency and necessity of conducting bottom-up, everyday empirical understandings of audiences as participating agents in the increasingly datafied culture. In wishing to promote this endeavor, notably, they echo the focus on 'reading' noted above, calling for " a renewed commitment to research widespread and fundamental audience experiences such as reading, viewing and interpreting, also with regards to social, digital and newer media developing a more careful balance between interest in production and other audience practices" (Das \& YtreArne 2017, 69).

Before proceeding with my argument, it is necessary to update and widen earlier definitions of reception research. Elsewhere I have suggested that the scope of reception research today should encompass "all forms of research which, irrespective of methodological approach, try to understand all audience sense-making processes around media, without privileging audiences' receptive interpretation of concrete media products" (Schrøder 2016, 1).

This definition, however, begs the question of whether there are any audiences to study at all in the present media culture. We are all familiar with Rosen's often quotes statement that from now on we must study "the people formerly known as the audience" (Rosen 2006), and reception scholars have 
asked if, when people are immersed in the culture of participation, "are they still audiences?" (Livingstone \& Das 2013, 104)

The bold and sweeping answer to this question is that in a deeply mediatized culture, people - at least those who have turned themselves into digital natives, who are online accessible during all their waking hours - are audiences all the time: they are never not audiences! As Livingstone has phrased it "where once people moved in and out of their status as audiences, using media for specific purposes and then doing something else $[\ldots]$ in our present age of continual immersion in media, we are now continually and unavoidable audiences at the same time as being consumers, relatives, workers, and [...] citizens and publics" (Livingstone 2013, 22). Thus we can define the term 'audience' as the people who, in their capacity of social actors, are attending to, negotiating the meaning of, and sometimes participating in the multimodal processes initiated or carried by institutional media. And as reception researchers we have something to offer for the study of such audiences.

As argued above, in its origins reception research was a crossroads, a site of cross-fertilization, a platform which reinvigorated its mother and father paradigms, before eventually establishing itself as an academic paradigm in its own right. In the remainder of this article, I shall discuss how it can play a similar formative role today, demonstrating some of the ways in which, as Livingstone \& Das $(2013,105)$ put it, "the critical repertoire of ideas and insights developed to rethink the mass television audience in the 1980 s and 1990s (...) is now coming into its own (...) to reveal its full analytic power ad potential".

The following discussion will consider four ways in which reception research is redefining itself for the digital age. First, reception researchers are continuing its foundational project by exploring sense-making audiences in the digital and social media landscape; secondly, reception research, 
jointly with audience research in general, can contribute to the 'audience turn' in mediatization research; then, in the form of brief pointers, I notice how reception research has an indispensable role to play in contextualizing datafied research through anchoring it in actors' meaningful practices; and how reception researchers are revitalizing qualitative methods in a methodological climate where mixed methods have become the new normal.

\section{Exploring sense-making across the digital and social media landscape}

I already noted that the suggested research agenda for audience analysis put forward by the Cedar Consortium included a commitment to continuing the research perspective practiced by reception research, i.e. to study 'readings' of media discourses in the age of social media. For instance, Jensen \& Sørensen (2014) have studied people's uses and experiences of online social networks like Facebook, combining insights drawn from netnographic analysis of users' Facebook profiles (Kozinets 2010), focus group discussions with users, and a web-based survey. Interestingly, this multi-method design echoes the once prescriptive recipe to combine a detailed textual analysis of the mediated content (such as a soap opera, or a news bulletin) with the ways audience members made sense of this textual content; only, when the mediated textual content is Facebook profiles, this content has not been produced by commercial cultural industries, but is co-produced by the Facebook users themselves and their platform friends. It can thus be said to be a discourse created by the very audiences whose reflections are analyzed through the qualitative and quantitative fieldwork.

Reception researchers have also recently pursued knowledge interests that echo some of the early reception studies of globally disseminated fiction formats. No less than two ambitiously large-scale comparative studies of The Hobbit Hollywood film trilogy, tracing audience responses to the 
cinema or home television screen experience, as well as their relations to fan practices in online games and on social media, have tried to answer the overall reception-analytical question (here in the phrase of one of them) “in what ways does something originating as an English children's story acquire meaning and value for different audiences across the world?" (Barker \& Mathijs 2016; see also Davis et al. 2016).

Among the specific research questions were, for instance, how different audiences understand the kind of film it is; how do audiences relate their responses to wider (real, digital, virtual or imagined) fan or non-fan communities; and to what extent they participate in online discussions and gaming? Using a hybrid qualitative/quantitative approach, the questionnaire experimented with different types of questions: in addition to standard closed questions, the questionnaire encompassed no less than eleven completely open questions with no word limit, such as "Who was your favourite character, in the book or the films? Can you say why?" The questionnaire was thus designed to both generate generalized patterns of viewers' experiences, and to understand the complex cultural meanings of the cinema-goers' experiences (Barker \& Mathijs 2016).

As demonstrated above, early reception research of the first stage (Hegemonic citizenship) sought to find out how audiences handled the hegemonic forces of the media, by applying dominant, negotiated, or oppositional reading strategies. In the Cedar mind-set, audiences today are facing a parallel scenario, where the hegemonic force of digital media manifests itself as an intrusive and potentially exploitative force in people's lives (Dhaenens and Mollen 2017). What we should study in this scenario, they suggest, is how audiences are coping with these intrusive media, by developing new forms of literacy that approach media as both technologies and processes of sensemaking. 
In this pursuit, they are struggling with some of the same conceptual problems that faced $1970 \mathrm{~s}$ reception research, notably the power of the mass media's preferred meanings: In the digital environment this is being translated into "the risk of oversimplifying, ascribing either too much or too little power to platforms" (p. 25). The earlier interest in dominant, negotiated and oppositional readings can be seen today to be mirrored in the focus on, respectively, coping and resistance strategies.

Mathieu \& Pavlíčková (2017) demonstrate how a reception-analytical approach is eminently suited for this kind of analysis, as they explore how the reading of Facebook's newsfeed - an inherent cross-media activity - can be seen as a sense-making activity that contributes to the construction of the user's mediated lifeworld. Among other things, they map the ways in which users 'cope' by applying 'upstream' reading strategies which control the algorithmic content flow before it appears in the newsfeed, and 'downstream' strategies to determine the immediate relevance of a post while reading the newsfeed.

As mentioned above, modern-day reception researchers are also populating the research terrain analyzing how audiences make sense of their mediated life-worlds, not least as part of the audience turn in journalism research. In addition to the work of Costera Meijer (2007), Bird (2011) explores with an ethnographic lens, which sees "news as a form of cultural meaning-making" (Bird 2011, 490), how news is inserted in everyday routines and how people talk about news. Heikkilä \& Ahva (2015) demonstrate the value of moving "beyond the determinate moments of reception - a given act of reading, watching or clicking - to grasp the broader environment wherein people encounter media products" (Heikkilä \& Ahva 2015, 52). 


\section{Promoting an audience turn in mediatization research}

Recently I have, with a term that has a somewhat tongue-in-cheek quality, suggested that mediatization research is in need of 'audiencization' (Schrøder 2017), due to the fact that the role of media audiences has until now not been recognized in mediatization research. After having reviewed recent authoritative research publications on mediatization, Lundby concluded that “audiences are more or less left out in mediatization research" (Lundby 2016: 2). Brants \& van Praag have argued that 'media logics', one of the central concepts of mediatization theory, "largely ignores $(\ldots)$ the place and importance of considerable parts of the public as a potentially empowered, active and participating force" (Brants \& van Praag 2017: 403; see also Witschge 2014 and Livingstone, in this special issue).

Conversely, one has to admit, in current reception research, that the advances made by mediatization theory during the last 8-10 years, are conspicuous by their absence. I would therefore suggest that mediatization research and reception research should take each other on board, as they both have a lot to gain from such a theoretical and empirical cross-fertilization.

Through such a rapprochement, audience reception research would benefit from the insights of one of the most promising ways to conceptualize the media/culture nexus, as it offers a holistic theory about how the media play a formative role in social and cultural transformations. The term 'formative role' is another way of saying that mediatization theory comes with a power perspective, which both goes beyond simplistic effect claims coming from media content, and beyond the technological-determinist medium theory. Instead mediatization theory considers the cross-media ensemble to be a moulding force on culture and society.

As I see it, of the two main varieties of mediatization research, institutionalist and constructivist, it is especially in institutionalist mediatization research that the individual audience member is merely 
seen as a reactive agent: someone who must learn how to adapt to and cope with the forces of mediatization, rather than as someone who is also actively implicated in the constitutive complexity of mediatization. This is not the place to go into details with the varieties of mediatization research, and nor is it productive to take sides and choose one over the other. Following the argument of Livingstone \& Lunt (2014), we should see the two varieties as complementary. They are suited for different purposes, as the institutionalist and constructivist perspectives can explain different aspects of the media/society nexus.

Suffice it to be said, therefore, that constructivist mediatization theory (see for instance Hepp 2013; Hasebrink \& Hepp 2017) lends itself more readily to a marriage with reception research, as it conceives of human actors as an essential unit of analysis. With a non-media-centric point of departure, constructivist mediatization theory focuses on constellations (or 'figurations') of communicating actors ('audiences'), who build their media repertoires out of the available media ensembles, in order to carry out their relevant activities. Constructivist mediatization research encompasses audience practices, but does not recognize the ways in which practices of agency may aggregate into a cumulative collective force. It is therefore in need of 'audiencization' (Schrøder 2017).

Reception research will do well to also seek marriage with institutionalist mediatization theory, which operates on the meso-societal level, analyzing the ways in which the media, conceptualized as a societal institution, interact with other societal institutions (Hjarvard 2013; Strömbäck 2008). In this process of institutional interaction, it is evidently correct that "other institutions to an increasing degree become dependent on resources that the media control, so that they will have to submit to some of the rules the media operate by in order to gain access to those resources" (Hjarvard 2013, 23). 
These 'rules' of the media manifest themselves as the so-called 'media logics', which are constituted by their properties: technological, aesthetic, and institutional, and increasingly impose themselves on other - political, religious, educational, etc. - institutions.

I have argued elsewhere (Schrøder 2017) that audience dynamics should be seen as a necessary part of the institutional anatomy of 'media logics', and that they therefore play an integral, formative role in the institutional influence exerted by the media in their interrelations with other societal institutions (see Figure 1). Historically and at any given point in time, the media institution, as well as specific media, is co-shaped by the ways in which audiences select and expose themselves to the media, the ways in which media discourses - directly or obliquely - mirror audience discourses, and the ways in which audience mobilizations may impinge directly on media behavior.

The 'audiencization' of mediatization thus means that any analysis of mediatization processes should in principle incorporate associated audience activities that derive from attention to or engagement with the media in question, considering how this audience activity exerts a formative influence, however small, on media and thereby on the relationship between the media and other societal institutions.

For Witschge (2014) and for Brants and van Praag (2017), the need to take audience dynamics seriously stems from the transformed role of audiences in the digital culture with the tendentially seamless relations between media consumption and production. My plea for the audiencization of mediatization research leans on a more fundamental understanding of the role that audiences have always played, in the broadcasting regime and further back into history, as a formative power on the entire communicative circuit of the media in society. 
Figure 1 about here

Adding 'audience dynamics' to the mutual adaptations to logics from various institutional domains (adapted from Hjarvard (2016).

The idea of audiencization chimes well with another innovative conceptual idea fostered by the Cedar researchers, that of 'small acts of engagement' (Kleut et al. 2017). What these two recent interventions share is the notion that "the main way in which members of the audience contribute to production is much more subtle than initially envisioned" (Kleut et al. 2017, 28). The Cedar analysis departs from the evident power of the media, showing itself in the way the digital media based on digital technologies exert intrusive power in the form of exploitation, pervasiveness and exclusion. However, the analysis argues that audiences and media are tied into a complex dialectical relationship, where audiences exercise power in small ways, namely by

1. One-click engagement, which encompasses a variety of acts, such as liking, sharing, and linking on social media platforms.

2. Commenting and debating, where "readers can consume but also actively participate in the production of news and popular culture" (Kleut et al. 2017, 28).

3. Production of small stories, which have to do with "social and cultural identity expressions, especially in the context of minority audiences or marginalized groups" (Kleut e al. 2017, 29).

Although each such act is quite insignificant, at the aggregate level "mainstream media flow can be challenged if not transformed due to the volume of these acts" (p. 30). Thus, as argued in connection with 'audiencization' processes, audiences are exercising power through inconspicuous 
everyday acts, which are thus one formative force alongside the technological, aesthetic, and institutional forces that shape the media institution at the highest level.

\section{Concluding remarks}

The above two ways to open new frontiers for reception research in the digital culture far from exhaust the opportunities for reception research to extend its own traditional agenda, while also creating enriching analytical insights of relevance to other scholarly areas, in audience research, in media and communication research, and beyond.

For instance, reception researchers are among the pioneers of audience research which exploits the fact that digital media automatically preserve data about the users and uses. Reception researchers have thus taken on board different methods for tracking media users' digital footprints, in smallscale as well as big data research designs. In keeping with the sense-making objectives of traditional reception research, such datafied research is usually combined with qualitative methods: Thorhauge \& Lomborg studied people's use of smartphone for cross-media experiences by combining log data with qualitative interviews, arguing that because log data "provide no insight into the social settings and the meanings of relationships enacted through the smartphone", qualitative insights are necessary "in order to re-embed the log data in their original contexts (...), and on this basis identify relevant practices of cross-media communication from the user's perspective" (Thorhauge \& Lomborg 2016, 76). In their study of how teachers and parents use and make sense of school information systems, Breiter and Hepp argue that it remains a challenge for reception analysis of big data use to work out "how we can analyze digital traces in such a way that we can contextualize them with the figurations of humans that produce these sequences of 'digital footprints', but also use them as a means for social construction" (Breiter \& Hepp 2017, 320).). 
In the area of methodological innovation, reception researchers have sought to revitalize the qualitative toolbox, in a methodological climate where mixed methods have become the new normal. However, while different methods have been seen as "complementary" when applied sequentially - i.e. a qualitative study followed by a survey, or vice versa (Jensen 2012), reception researchers have pushed the methodological boundaries by integrating qualitative and quantitative methods within the same fieldwork implement (Greene 2007; Schrøder 2012b). These experiments, which have relied on modified versions of Q-methodology, have been applied in studies of fiction (Davis et al. 2016) as well as news reception (Kobbernagel \& Schrøder 2016), with the purpose of overcoming the challenges of producing reliable qualitative generalization. The output of a Qmethodological study, which passes qualitative data through a factor analysis to produce a typology of audience experiences (Davis \& Michelle 2011), can thus be said to have answered one of the very old questions in reception research about methodological cross-fertilization - "whether a method can be devised which combines the insightfulness and detail of the qualitative approach with the generality and economy of quantification" (Schrøder 1987).

\section{References}

Ang, Ien. 1996. Living Room Wars. Rethinking Media Audiences for a Postmodern World, London: Routledge.

Barker, Martin \& Ernest Mathijs. 2016. "The World Hobbit Project: Introduction to the project.” Participations, 13 (2): 158-174. 
Biltereyst, Daniel. 1991. "Resisting the American hegemony: A comparative analysis of the reception of domestic and US fiction." European journal of communication 6: 469-497.

Bird, S. Elizabeth. 2011. "Seeking the Audience for News. Response, News Talk, and Everyday Practices." In The Handbook of Media Audiences, edited by Virginia Nightingale, 489-508. Oxford: Blackwell.

Blumler, Jay G., Michael Gurevich, and Elihu Katz. 1985. "Reaching Out: A Future for Gratifications Research.” In Media Gratifications Research, edited by Karl E. Rosengren. Lawrence A.Wenner and Philip Palmgreen, 225-274. Beverly Hills: Sage, 1985.

Brants, Kees and Philip van Praag. 2017. "Beyond Media Logic.” Journalism Studies 17 (4): 395 408.

Breiter, Andreas and Andreas Hepp. 2017. "The Complexity of Datafication: Putting Digital Traces in Context." In Communicative Figurations: Transforming Communications in Times of Deep Mediatization, edited by Andreas Hepp, Andreas Breiter and Uwe Hasebrink, 387-404. London: Palgrave-Macmillan.

Carpentier, Nico.2003. “The BBC's Video Nation as a participatory media practice. Signifying everyday life, cultural diversity and participation in an online community." International journal of cultural studies 6 (4) 425-447.

Costera Meijer, Irene. 2007. “The Paradox of Popularity: How Young People Experience the News.” Journalism Studies 8 (1): 96-116.

Das, Ranjana and Brita, Ytre-Arne, eds. 2017. Audiences Towards 2030. Priorities for Audience Analysis. Surrey: CEDAR. 
Das, Ranjana and Brita, Ytre-Arne, eds. 2018. The future of audiences. A foresight analysis of interfaces and engagement. Cham: Palgrave Macmillan US.

Davis, Charles H. and Carolyn Michelle. 2011. "Q Methodology in Audience Research: Bridging the Qualitative/ Quantitative ‘Divide’?’ Participations 8 (2): 559-593.

Davis, Charles, Carolyn Michelle, Ann Hardy, and Craig Hight, Craig. 2016. "Making global audiences for a Hollywood "blockbuster" feature film: marketability, playability, and The Hobbit: An Unexpected Journey.” Journal of Fandom Studies 4 (19: 105-125.

Deacon, David, Natalie Fenton and Alan Bryman. 1999. "From inception to reception: The natural history of a news item." Media, culture \& society 21: 5-31.

Dervin, Brenda. 1989. “Audience as listener and learner, teacher and confidante: The sense-making approach.” In Public communication campaigns, edited by Ron E. Rice and C.K. Atkin, 67-86. London: Sage.

Dhaenens, Frederik and Anne Mollen. “Coping with Intrusive Digital Media.” In Audiences Towards 2030. Priorities for Audience Analysis, edited by Ranjana Das and Brita Ytre-Arne, 25-27. Surrey: CEDAR, 2017.

Dhoest, Alexander. "Establishing a multi-ethnic imagined community? Ethnic minority audiences watching Flemish soaps.” European Journal of Communication 24 (3): 305-323.

Fiske, John. 1987. Television Culture. London: Methuen.

Fiske, John, and John Hartley 1978. Reading television. London: Methuen.

Gillespie, Marie. 1995. Television, Ethnicity, and Cultural Change. London: Routledge.

Gray, Ann. 1992. Video playtime: The gendering of a leisure technology. London: Routledge. 
Greene, Jennifer C. 2007. Mixed methods in social inquiry, San Francisco: Jossey-Bass.

Gurevitch, Michael \& Paddy, Scannell. 2003. “Canonization achieved? Stuart Hall's

'Encoding/Decoding'." In Canonic texts in media research. Are there any? Should there be? How about these? edited by Elihu Katz, John D. Peters, Tamar Liebes and Avril Orloff, Cambridge: Polity Press.

Hall, Stuart. 1973. "Encoding and decoding in the television discourse." Stencilled occasional paper, Media Series No.7, Centre for Contemporary Cultural Studies, University of Birmingham. Abridged version.

Hasebrink, Uwe and Andreas Hepp 2017. "How to research cross-media practices? Investigating media repertoires and media ensembles." Convergence: The International Journal of Research into New Media Technologies 23 (4): 362-377.

Heikkilä, Heikki and Laura Ahva. 2015. "The Relevance of Journalism. Studying News Audiences in a Digital Era.” Journalism Practice 9 (1): 50-64.

Hepp, Andreas. 2013. Cultures of mediatization. Cambridge: Polity.

Hjarvard, Stig. 2013. The mediatization of culture and society. New York: Routledge.

Hjarvard, Stig. 2016. “Medialisering: teori og historie.” In Medialisering. Mediernes rolle i social og kulturel forandring, edited by Stig Hjarvard, 17-38. København: Hans Reitzel.

Hoggart, Richard. 1957. The uses of literacy. Harmondsworth: Penguin.

Jensen, Jakob L. and Anne S. Sørensen. 2014. ”Analyzing online social networks from a user perspective: A quantitative-qualitative framework." In Audience research methodologies: Between 
innovation and consolidation, edited by Geoffroy Patriarche, Helena Bilandzic, Jakob L. Jensen and Jelena Jurisiić, 144-159. New York, NY: Routledge.

Jensen, Klaus B. Making sense of the news. Aarhus, Denmark: Aarhus University Press, 1986.

Jensen, Klaus B. 1991. "Reception analysis: mass communication as the social production of meaning." In A Handbook of Qualitative Methodologies for Mass Communication Research, edited by Klaus B. Jensen and Nick W. Jankowski, 135-48. London: Routledge.

Jensen, Klaus B. 2012. “The complementarity of quantitative and qualitative methodologies in media and communication research." In A handbook of media and communication research, edited by Klaus B. Jensen, London: Routledge, $2^{\text {nd }}$.

Jensen, Klaus Bruhn and Karl Erik, Rosengren. 1990. "Five traditions in search of the audience." European journal of communication 5: 207-38.

Jones, Jeffrey P. 2006. “A Cultural Approach to the Study of Mediated Citizenship.” Social Semiotics, 16 (2): 365-383.

Katz, Elihu and Tamar Liebes. 1985. "The Export of Meaning: Cross Cultural Readings of American TV.” Paper presented to the Manchester Symposium on Broadcasting, March 1985.

Kobbernagel, Christian, and Kim C. Schrøder. 2016. "From everyday communicative figurations to rigorous audience news repertoires. A mixed method approach to cross-media news consumption." Mediekultur 32 (60): 6-31.

Kleut, Jelena, Jannie M. Hartley, Tereza Pavlíčková, Ike Picone, Bojana Romic, and Sander de Ridder. "Small Acts of Audience Engagement Interrupting Content Flows.”, in Das, Ranjana \& Brita Ytre-Arne: 28-30. 
Kormelink, Tim Groot and Irene Costera Meijer. 2017. "What clicks actually mean: Exploring digital news user practices.” Journalism https://doi.org/10.1177/1464884916688290

Kozinets, Robert V. 2010. Netnography: Doing Ethnographic Research Online. Los Angeles, CA: Sage.

Lewis, Justin. 1991. The ideological octopus. An exploration of television and its audience. New York: Routledge.

Liebes, Tamar and Elihu Katz. 1990. The Export of Meaning. New York: Oxford University Press.

Livingstone, Sonia. 1988. "Viewers' interpretations of soap opera: the role of gender, power and morality." In Television and its audience, edited by Philip Drummond and Richard Paterson, 83107. London: British Film Institute.

Livingstone, Sonia. 2013. "The participation paradigm in audience research.” The Communication Review 16: 21-30.

Livingstone, Sonia and Ranjana Das. 2012. "The end of audiences? Theoretical echoes of reception amidst the uncertainties of use". In A companion to new media dynamics, edited by John Hartley, Jean Burgess and Axel Bruns, 104-121. Chichester, UK: Wiley-Blackwell.

Livingstone, Sonia and Peter Lunt. 1994. Talk on television. London: Routledge.

Livingstone, Sonia, and Peter Lunt. 2014. "Mediatization: An emerging paradigm for media and communication research?” In Mediatization of communication, edited by Knut Lundby, 703-723. Berlin, Boston: De Gruyter/Mouton. 
Livingstone, Sonia, Mallory Wober and Peter Lunt. 1994. "Studio Audience Discussion Programmes: An Analysis of Viewers' Preferences and Involvement.” European Journal of Communication $9: 355-379$.

Lull, James. 1980. “The social uses of television.” Human communication research 6: 197-209.

Lundby, Knut. 2016. "Where are audiences in mediatization research?” Paper for the Mediatization section of the $6^{\text {th }}$ ECREA conference, Prague 9-12 November 2016.

Mathieu, David and Tereza Pavlíčková. 2917. “Cross-media within the Facebook newsfeed: The role of the reader in cross-media uses." Convergence 23 (4): 425-438.

Morley, David. 1980. The 'Nationwide' audience. London: British Film Institute.

Morley, David. 1986. Family Television. London: Comedia.

Radway, Janice. 1984. Reading the romance: women, patriarchy and popular literature. Chapel Hill: University of North Carolina Press.

Rosen, Jay. 2006. The People Formerly Known as the Audience, PressThink. http://archive.pressthink.org/2006/06/27/ppl_frmr.html.

Schiller, Herbert I. 1971. Mass communication and American empire. Boston: Beacon Press.

Schrøder, Kim C. 1987. "Convergence of Antagonistic Traditions? The Case of Audience Research." European Journal of Communication 2 (1) 7-31.

Schrøder, Kim C. 1992. "Cultural Quality: Search for a Phantom?" In Media Cultures Reappraising Transnational Media, edited by Michael Skovmand and Kim Schrøder, 199-219. London and New York: Routledge. 
Schrøder, Kim C. 2012a. "From Semiotic Resistance to Civic Agency: Viewing Citizenship Through the Lens of Reception Research 1973-2010.” In The Social Use of Media. Cultural and Social Scientific Perspectives on Audience Research, edited by Helena Bilandzic, Geoffroy Patriarche and Paul J. Traudt. 181-200. London: Intellect.

Schrøder, Kim C. 2012b. "Methodological pluralism as a vehicle of qualitative generalization." Participations. Journal of audience and reception studies 9 (2): 798-825.

Schrøder, Kim C. 2016. "Reception analysis." In The International Encyclopedia of Political Communication, edited by Gianpietro Mazzoleni, Oxford: Wiley/Blackwell.

Schrøder, Kim C. 2017. "Towards the "Audiencization" of Mediatization Research? - Audience Dynamics as Co-Constitutive of Mediatization Processes.” In Dynamics of Mediatization: Institutional Change and Everyday Transformations in a Digital Age, edited by Olivier Driessens, Göran Bolin, Andreas Hepp and Stig Hjarvard, 85-115. London: Palgrave Macmillan.

Strömbäck, Jesper. 2008. "Four phases of mediatization: An analysis of the mediatization of politics." The International Journal of Press/Politics 13 (3): 228-246.

Thorhauge, Anne Mette and Stine Lomborg. 2016. "Cross-media Communication in Context. A Multi-Method Approach." Mediekultur 60: 70-86.

Wahl-Jørgensen, Karin, Andrew Williams and Claire Wardle. 2010. “Audience views on usergenerated content: Exploring the value of news from the bottom up." Northern Lights 8, Yearbook of Film and Media Studies, Bristol, UK, Intellect Press: 177-194.

Williams, Raymond. 1958. Culture and society. London: Chatto and Windus. 
Witschge, Tamara. 2014. "Passive accomplice or active disruptor. The role of audiences in the mediatization of politics". Journalism Practice 8, no. 3: 342-356. 
Kim Christian Schrøder,

Audience reception research in a post-broadcasting digital age

The logics of the media The logics of a particular institutional domain (e.g. politics, education)

Technology (Hard-ware, Infrastructure)

Aesthetics (Genres, modes

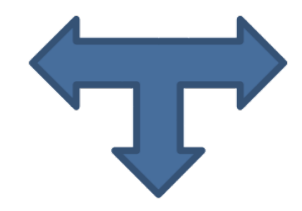

Resources: material and symbolic

Rules: formal and informal rules of narration)

Institutional (Regulatory

framework, organization)

NEW: Audience dynamics

(media selection,

interpretation, participation)

\section{Outcomes:}

The mediatization of politics/The politicization of the media The mediatization of education/The educationalization of media

Figure 1 Adding 'audience dynamics' to the mutual adaptations to logics from various institutional domains (adapted from Hjarvard (2016). 